\title{
Correction to: Predictors of timely diagnostic follow-up after an abnormal Pap test among Hispanic women seeking care in El Paso, Texas
}

Thelma Carrillo ${ }^{1}$, Jane R. Montealegre ${ }^{2,3}$, Christina G. Bracamontes ${ }^{1}$, Michael E. Scheurer ${ }^{2,3}$, Michele Follen ${ }^{1,4}$ and Zuber D. Mulla ${ }^{1,5^{*}}$

\section{Correction to: BMC Women's Health (2021) 21:11}

https://doi.org/10.1186/s12905-020-01161-9

Following publication of the original article [1], we were notified of a typographical error in the Conclusions section of the Abstract: " $\leq 30$ years" should actually read " $<30$ years".

The original article has been corrected.

\section{Reference}

1. Carrillo T, et al. Predictors of timely diagnostic follow-up after an abnormal Pap test among Hispanic women seeking care in El Paso, Texas. BMC Women's Health. 2021;21:11. https://doi.org/10.1186/s12905-020-01161-9.

\section{Publisher's Note}

Springer Nature remains neutral with regard to jurisdictional claims in published maps and institutional affiliations.

\begin{abstract}
Author details
${ }^{1}$ Department of Obstetrics and Gynecology, Paul L. Foster School of Medicine, Texas Tech University Health Sciences Center El Paso, El Paso, TX, USA. ${ }^{2}$ Department of Pediatrics, Baylor College of Medicine, Houston, TX, USA. ${ }^{3}$ Dan L. Duncan Comprehensive Cancer Center, Baylor College of Medicine, Houston, TX, USA. ${ }^{4}$ Present Address: NYC Health + Hospitals| Kings County, Brooklyn, NY, USA. ${ }^{5}$ Office of Faculty Development (MSC 21007, Texas Tech University Health Sciences Center El Paso, 5001 El Paso Drive, El Paso, TX 79905, USA.
\end{abstract}

Published online: 27 January 2021
The original article can be found online at https://doi.org/10.1186/s1290 5-020-01161-9.

*Correspondence: zuber.mulla@ttuhsc.edu

1 Department of Obstetrics and Gynecology, Paul L. Foster School

of Medicine, Texas Tech University Health Sciences Center El Paso, El Paso,

TX, USA

Full list of author information is available at the end of the article

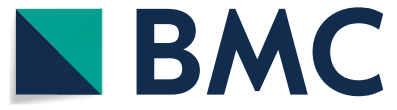

(c) The Author(s) 2021. Open Access This article is licensed under a Creative Commons Attribution 4.0 International License, which permits use, sharing, adaptation, distribution and reproduction in any medium or format, as long as you give appropriate credit to the original author(s) and the source, provide a link to the Creative Commons licence, and indicate if changes were made. The images or other third party material in this article are included in the article's Creative Commons licence, unless indicated otherwise in a credit line to the material. If material is not included in the article's Creative Commons licence and your intended use is not permitted by statutory regulation or exceeds the permitted use, you will need to obtain permission directly from the copyright holder. To view a copy of this licence, visit http://creativecommons.org/licenses/by/4.0/. The Creative Commons Public Domain Dedication waiver (http://creativeco mmons.org/publicdomain/zero/1.0/) applies to the data made available in this article, unless otherwise stated in a credit line to the data. 